\title{
Characterization of Amino Acid Side Chain Losses in Electron Capture Dissociation
}

\author{
Helen J. Cooper, Robert R. Hudgins, Kristina Håkansson, \\ and Alan G. Marshall* \\ Ion Cyclotron Resonance Program, National High Magnetic Field Laboratory, Florida State University, \\ Tallahassee, Florida, USA
}

\begin{abstract}
We have used electrospray ionization (ESI) Fourier-transform ion cyclotron resonance (FTICR) mass spectrometry to characterize amino acid side chain losses observed during electron capture dissociation (ECD) of ten 7- to 14-mer peptides. Side-chain cleavages were observed for arginine, histidine, asparagine or glutamine, methionine, and lysine residues. All peptides containing an arginine, histidine, asparagine or glutamine showed the losses associated with that residue. Methionine side-chain loss was observed for doubly-protonated bombesin. Lysine side-chain loss was observed for triply-protonated dynorphin A fragment 1-13 but not for the doubly-protonated ion. The proximity of arginine to a methoxy C-terminal group significantly enhances the extent of side-chain fragmentation. Fragment ions associated with side-chain losses were comparable in abundance to those resulting from backbone cleavage in all cases. In the ECD spectrum of one peptide, the major product was due to fragmentation within an arginine side chain. Our results suggest that cleavages within side chains should be taken into account in analysis of ECD mass spectral data. Losses from arginine, histidine, and asparigine/glutamine can be used to ascertain their presence, as in the analysis of unknown peptides, particularly those with non-linear structures. (J Am Soc Mass Spectrom 2002, 13, 241-249) ( 2002 American Society for Mass Spectrometry
\end{abstract}

$\mathrm{T}$ The introduction of electron capture dissociation (ECD) $[1,2]$ to electrospray ionization (ESI) [3-6] Fourier-transform ion cyclotron resonance mass spectrometry (FT-ICR MS) [7, 8] constitutes a significant advance in the analysis of peptides and proteins. Tandem mass spectrometry [9], in which a precursor ion is characterized according to its product fragments was already well established as a method for obtaining structural information. Techniques for inducing fragmentation in FT-ICR MS include sustained off-resonance irradiation collision-induced dissociation (SORICID) [10], infrared multiphoton dissociation (IRMPD) $[11,12]$, blackbody infrared radiative dissociation (BIRD) $[13,14]$, and surface-induced dissociation [15, 16]. Additional front-end techniques, in which ions are fragmented before they reach the ICR trapped-ion cell, include multipole storage assisted dissociation (MSAD) $[17,18]$ and nozzle-skimmer fragmentation [19]. All of these fragmentation techniques may result in cleavage of backbone amide bonds of a gas-phase peptide ion to form $b$ and y product ions [20].

ECD is unique in that it typically produces $\mathrm{c}$ and $\mathrm{z}$.

Published online January 8, 2002

Address reprint requests to Dr. A. G. Marshall, National High Magnetic Field Laboratory, Florida State University, 1800 E. Paul Dirac Drive, Tallahassee, FL 32310, USA. E-mail: marshall@magnet.fsu.edu

*Member of the Department of Chemistry, Florida State University, Tallahassee, FL, USA. ions. Following electron capture, a hydrogen atom is proposed to be captured by a carbonyl oxygen. Subsequent bond rearrangement results in cleavage of the backbone amine bond $[2,21]$. The extent of cleavage along the backbone in ECD is typically far greater than that for other fragmentation techniques. Notably, no cleavage is seen on the $\mathrm{N}$-terminal side of proline because of its cyclic structure. However, a peptide containing proline may nevertheless be sequenced by ECD. In general, neighboring amino acids have little influence on ECD backbone cleavage although cleavage on the C-terminal side of tryptophan has been reported to be favored and little cleavage is seen on either side of cysteine [22]. Initial studies by Kruger et al. [23] demonstrated the possibility of sequencing entire peptides solely by ECD. More recently, Håkansson et al. [24] sequenced peptides at 200-2000 times lower concentration than previously reported. McLafferty and co-workers [25] correctly determined the sequence of melittin $(2.8 \mathrm{kDa})$ and ubiquitin $(8.6 \mathrm{kDa})$ from their ECD and CID spectra by use of a de novo sequencing algorithm [26]. That approach was further improved by activated ion electron capture dissociation (AI ECD) in which ions collide with a background gas while subjected to ECD [27]. Virtually complete sequence coverage of myoglobin and extensive sequence information in the terminal regions of 29,30 , and $42 \mathrm{kDa}$ proteins could thereby be achieved. 
LHRH: pGlu-His-Trp-Ser-Tyr-Gly-Leu-Arg-Pro-Gly- $\mathrm{NH}_{2}$

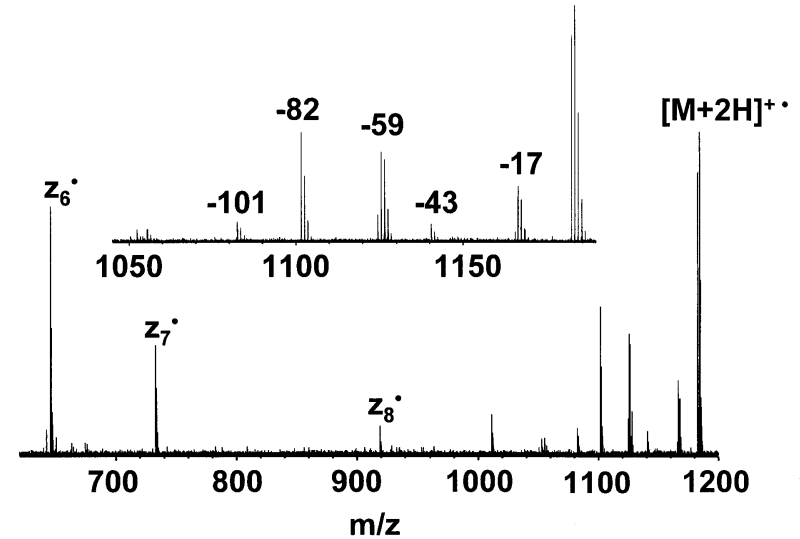

Figure 1. ESI ECD FT-ICR $m / z$ spectrum of LHRH $[\mathrm{M}+2 \mathrm{H}]^{2+}$

A particularly attractive feature of ECD is that, unlike the products of other fragmentation techniques, ECD backbone fragments tend to retain post-translational modifications. Kelleher et al. [28] showed that sites of $\gamma$-carboxyglutamic acid residues and sulfated side chains could be characterized. Further work showed that sites of O-glycosylation [29], phosphorylation [30,31] and N-glycosylation [32] could be localized.

Another feature of ECD is its ability to cleave disulfide bonds [21,33]. In fact, such cleavage is favored over backbone cleavage. Other fragmentation techniques do not favor cleavage of disulfide bonds, thereby limiting structural information. This problem may be circumvented by reduction of the disulfide bonds prior to MS/MS analysis [34], but at the cost of a longer experiment and greater required sample amount. The mechanism for disulfide cleavage in ECD is believed to differ from that of backbone cleavage [33, 35].

In spite of numerous examples of electron capture dissociation, scant attention has been paid to amino acid side chain losses. Losses attributed to lysine and arginine side chains were noted in passing in the

Neurotensin:

pGlu-Leu-Tyr-Glu-Asn-Lys-Pro-Arg-Arg-Pro-Tyr-Ile-Leu

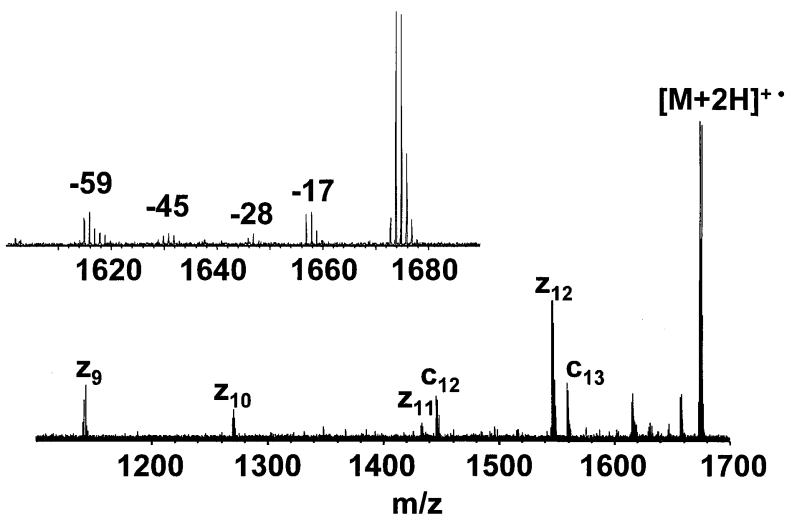

Figure 2. ESI ECD FT-ICR $\mathrm{m} / \mathrm{z}$ spectrum of neurotensin $[\mathrm{M}+$ $2 \mathrm{H}]^{2+}$.
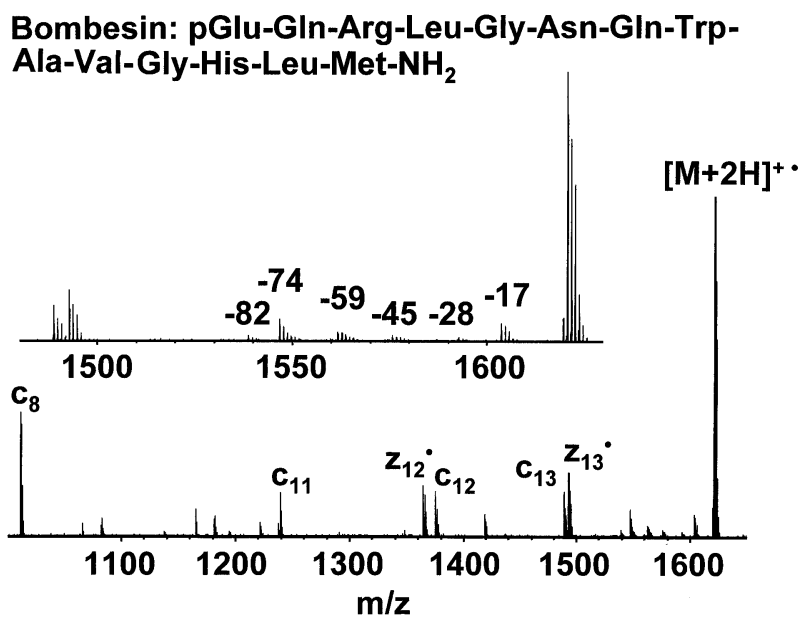

Figure 3. ESI ECD FT-ICR $m / z$ spectrum of bombesin $[\mathrm{M}+$ $2 \mathrm{H}]^{2+}$.

original study [1]. While using ECD to investigate the structure of $b^{2+}$ ions, Haselmann et al. [36] noted the loss of a histidine side chain. This behavior was rationalized by neutralization of the nearby acylium site because the histidine residue was situated close to the C-terminus. Our present results suggest that, far from being inconsequential, side chain losses can constitute important fragmentation pathways, in some cases the major fragmentation pathway in electron capture dissociation of peptides.

\section{Experimental Methods}

\section{Samples}

Luteinizing hormone releasing hormone (LHRH), neurotensin, bombesin, and dynorphin A fragment 1-13 were purchased from Sigma (St. Louis, MO) and used without further purification. The peptides ALANGMARSHALL, ALANGFARSHALL, ALANGPARSHALF, RSHRGHR,

Dynorphin A Fragment 1-13:

Tyr-Gly-Gly-Phe-Leu-Arg-Arg-Ile-Arg-Pro-Lys-Leu-Lys

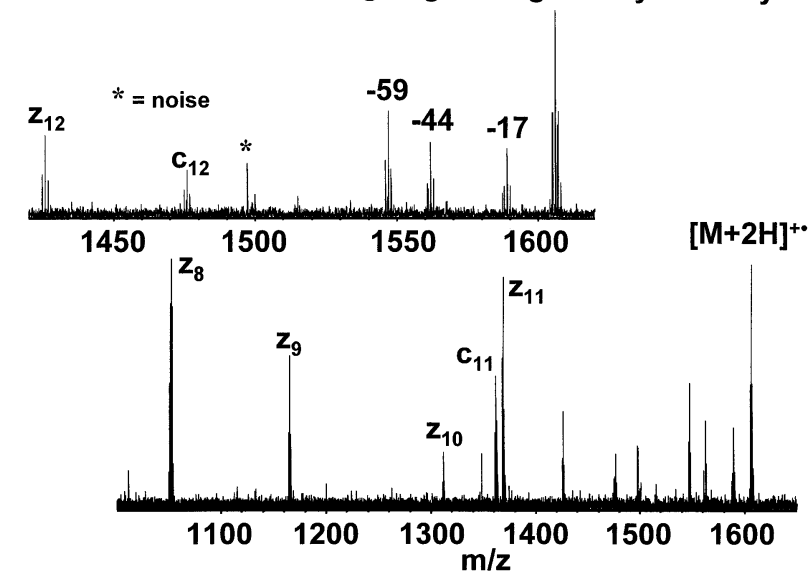

Figure 4. ESI ECD FT-ICR $\mathrm{m} / \mathrm{z}$ spectrum of dynorphin A fragment $1-13[\mathrm{M}+2 \mathrm{H}]^{2+}$. 
ALANGMARSHALL

Ala-Leu-Ala-Asn-Gly-Met-Ala-Arg-Ser-His-Ala-Leu-Leu

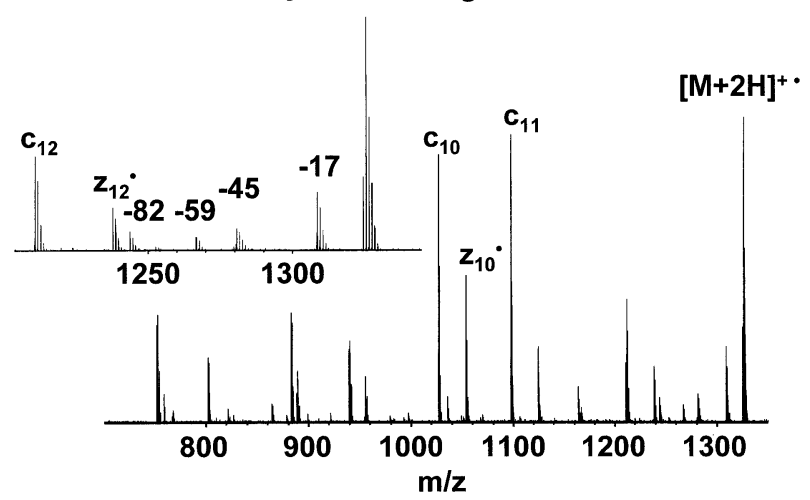

Figure 5. ECD FT-ICR $\mathrm{m} / \mathrm{z}$ spectrum of ALANGMARSHALL $[\mathrm{M}+2 \mathrm{H}]^{2+}$.

RPPGFSPFROCH ${ }_{3}$, and the disulfide-linked dimer of AcCAAAAAK were synthesized by the BASS facility at Florida State University. The samples were electrosprayed from solutions of 1:1 water:methanol (J. T. Baker, Philipsburg, NJ), 2\% acetic acid (Aldrich, Milwaukee, WI) at 10 $\mu \mathrm{M}$ concentration.

\section{Electron Capture Dissociation FT-ICR Mass Spectrometry}

The peptide samples were analyzed with a homebuilt, passively shielded, 9.4 tesla FT-ICR mass spectrometer [37] equipped with an external microelectrospray ionization source [38]. The samples were infused at a flow rate of $300 \mathrm{~nL} / \mathrm{min}$ through an electrospray emitter consisting of a $50 \mu \mathrm{m}$ i.d. fused silica capillary which had been mechanically ground to a uniform thin-walled tip [39]. $1.8 \mathrm{kV}$ was applied between the microspray emitter and the capillary entrance. The electrosprayed ions were delivered into the mass spectrometer through a Chait-style atmosphere-to-vacuum interface [40] and externally accumulated [38] for $3 \mathrm{~s}$ in a $45 \mathrm{~cm}$ rf-only

\section{ALANGFARSHALL}
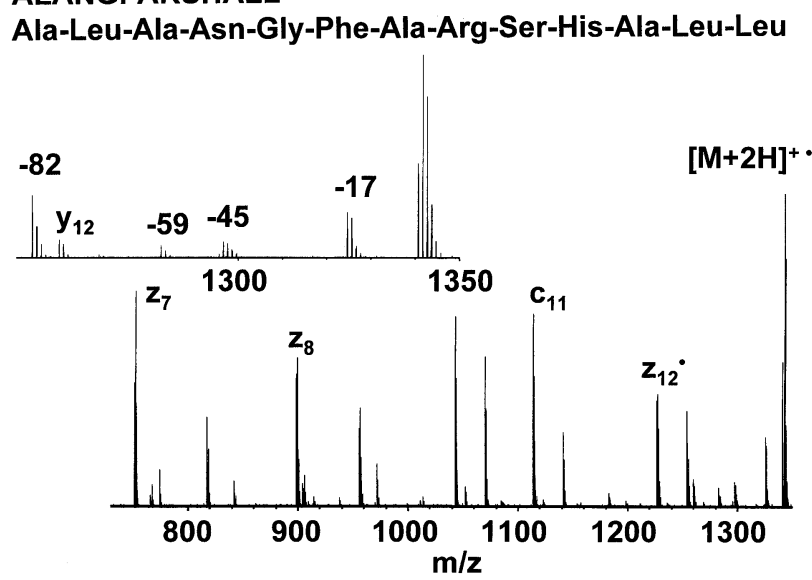

Figure 6. ESI ECD FT-ICR $\mathrm{m} / \mathrm{z}$ spectrum of ALANGFARSHALL $[\mathrm{M}+2 \mathrm{H}]^{2+}$.
ALANGPARSHALF:

Ala-Leu-Ala-Asn-Gly-Pro-Ala-Arg-Ser-His-Ala-Leu-Phe

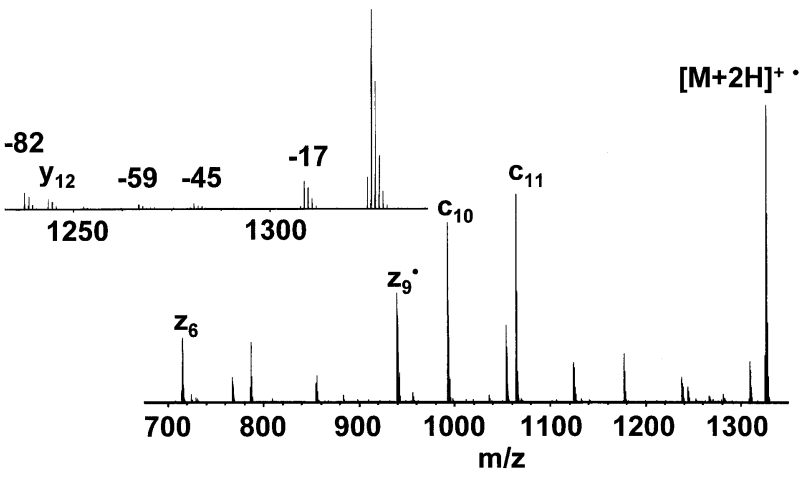

Figure 7. ESI ECD FT-ICR $\mathrm{m} / \mathrm{z}$ spectrum of ALANGPARSHALF $[\mathrm{M}+2 \mathrm{H}]^{2+}$.

octapole. The ions were transferred through multipole ion guides and trapped in an open [41] cylindrical cell (Malmberg-Penning trap [42]). Stored-waveform inverse Fourier transform (SWIFT) [43-45] ejection served to isolate the peptide ion under investigation.

A heated filament electron gun installed $\sim 1 \mathrm{~m}$ behind the FT-ICR cell provided the electrons for ECD [46]. The gun is probe-mounted on a flexible bellows and can be tilted and translated for optimal placement in the field. The filament was biased at $3.83 \mathrm{~V}$ at one end and the heating current adjusted to get a potential drop of between 2.0 and $2.3 \mathrm{~V}$ across the filament. A voltage of $-8 \mathrm{~V}$ was applied to a repeller plate located behind the filament to increase the number of electrons interacting with the trapped ions [24]. A grid situated in front of the filament was kept at $-80 \mathrm{~V}$ for most of the experiment and pulsed to $+20 \mathrm{~V}$ during the ECD event. The isolated parent ions were irradiated with electrons for $30 \mathrm{~s}$.

The ECD fragment ions were frequency-sweep (chirp) [47] excited (58 to $1280 \mathrm{kHz}$ at $150 \mathrm{~Hz} / \mu \mathrm{s}$ ) and detected in direct mode (512 Kword time-domain data).

\section{Arg-Ser-His-Arg-Gly-His-Arg}

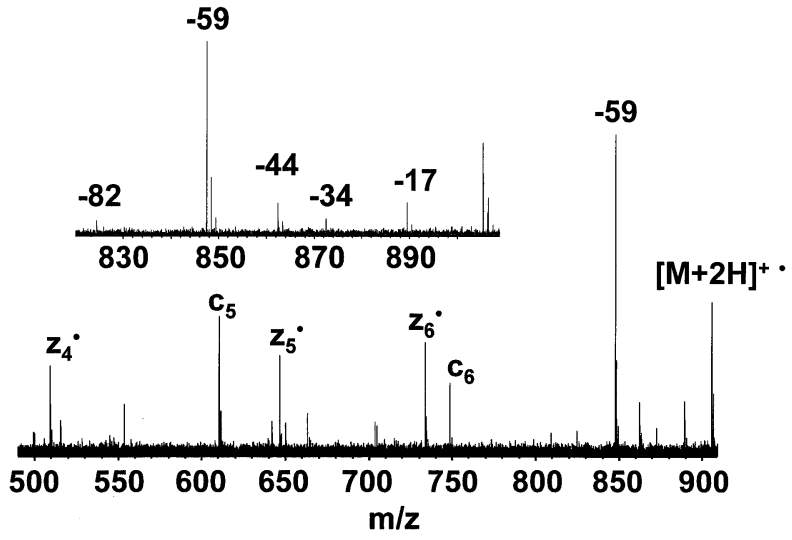

Figure 8. ESI ECD FT-ICR $m / z$ spectrum of RSHRGHR [M + $2 \mathrm{H}]^{2+}$. 


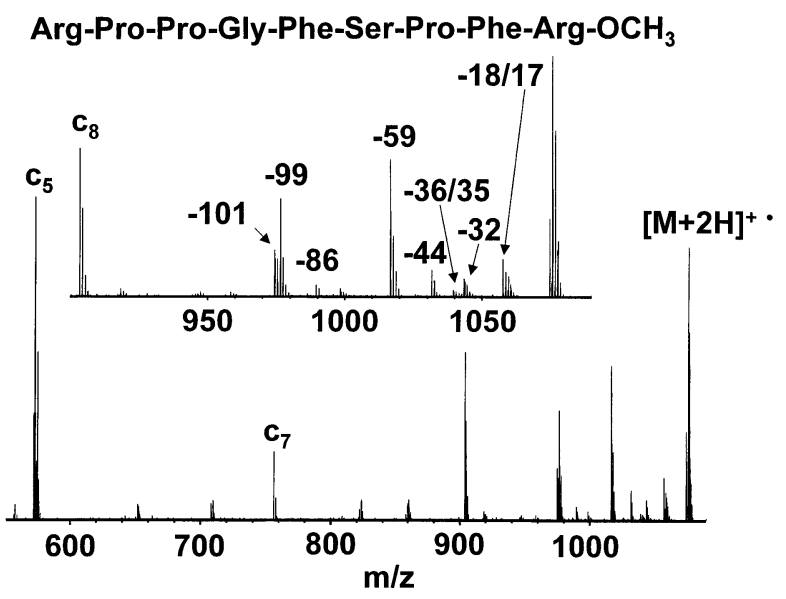

Figure 9. ESI ECD FT-ICR $\mathrm{m} / \mathrm{z}$ spectrum of RPPGFSPFROCH $[\mathrm{M}+2 \mathrm{H}]^{2+}$.

Between fifteen and forty time-domain data sets were co-added, Hanning apodized (to smooth the line shape) [48], zero-filled once (to increase digital resolution) [48], and subjected to fast Fourier transform (FFT) followed by magnitude calculation. The experimental event sequence was controlled by a modular ICR data acquisition system (MIDAS) [49]. The FT-ICR mass spectra were internally frequency-to- $m / z$ calibrated $[50,51]$ with respect to parent $[\mathrm{M}+\mathrm{nH}]^{\mathrm{n}+},[\mathrm{M}+\mathrm{nH}]^{(\mathrm{n}-1)+}$, and $\mathrm{c}, \mathrm{z}$, or $\mathrm{z}$ - fragment ions. The root mean square errors in all of the spectra were less than $1.0 \mathrm{ppm}$, for a mass accuracy of $\sim 3$ ppm or less. The FT-ICR mass spectra were analyzed by use of the MIDAS analysis software package [52].

\section{Results and Discussion}

\section{Doubly-Protonated Peptide Ions}

The ECD ESI FT-ICR mass spectra of the doublyprotonated peptides LHRH, neurotensin, bombesin,

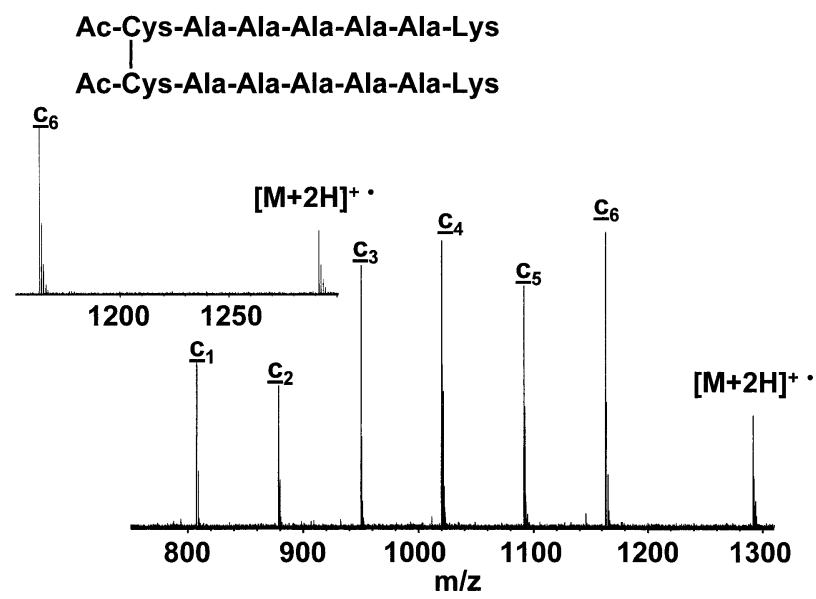

Figure 10. ESI ECD FT-ICR $\mathrm{m} / \mathrm{z}$ spectrum of the disulfide-linked dimer of Ac-CAAAAAK $[\mathrm{M}+2 \mathrm{H}]^{2+}$. The $\underline{\mathrm{c}}_{n}$ notation refers to $\mathrm{c}_{n}$ fragments still disulfide-linked to an intact monomer.

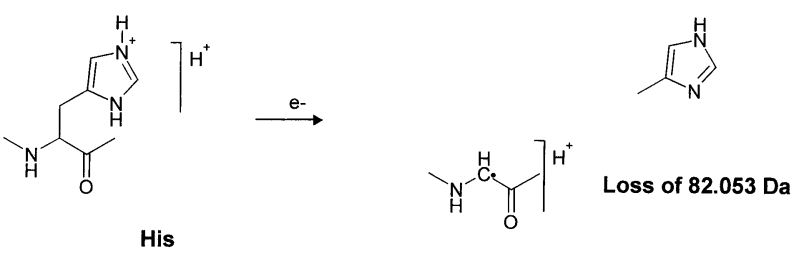

Scheme 1

dynorphin A fragment 1-13, ALANGMARSHALL, ALANGFARSHALL, ALANGPARSHALF, RSHRGHR, $\mathrm{RPPGFSPFROCH}_{3}$, and the disulfide-linked dimer of AcCAAAAAK are shown in Figures 1, 2, 3, 4, 5, 6, 7, 8, 9 , and 10. Side-chain losses and major backbone fragments (c, z, or $\mathrm{z} \cdot$ ) are indicated.

The ECD mass spectrum of $\mathrm{LHRH}^{2+}$ (pGlu-His-TrpSer-Tyr-Gly-Leu-Arg-Pro-Gly- $\mathrm{NH}_{2}$ ) contains peaks attributed to side chain losses from the amino acids His and Arg. The peak at $m / z 1101.5374$ constitutes a loss of 82.051 Da from the $[\mathrm{M}+2 \mathrm{H}]^{+\cdot}$ ion, and corresponds to the elemental composition, $\mathrm{C}_{4} \mathrm{H}_{6} \mathrm{~N}_{2}$ (82.053 Da), i.e., the His side chain (see Scheme 1). Bombesin, ALANGMAR SHALL, ALANGFARSHALL, ALANGPARSHALF, and RSHRGHR all contain His and showed losses of 82.053, $82.055,82.050,82.048$, and $82.051 \mathrm{Da}$ from the $[\mathrm{M}+2 \mathrm{H}]^{+}$. ion respectively. The remaining peptides do not contain His and no losses of $\sim 82 \mathrm{Da}$ were observed. His sidechain loss has been reported previously in the ECD spectra of bombesin $b_{12}^{2+}$ and $b_{13}^{2+}$ ions [36]. In these ions, His is either at $\left(b_{12}^{2+}\right)$ or next to $\left(b_{13}^{2+}\right)$ the $C$-terminus and the observation was explained by neutralization of the nearby acylium site. In contrast, the above-mentioned peptides have His at various points along the backbone and His side-chain loss was nevertheless observed in each case.

The peaks at $m / z 1124.5437$ and 1082.4957 in the ECD spectrum of $\mathrm{LHRH}^{2+}$ correspond to losses of 59.045 $\left(\mathrm{CH}_{5} \mathrm{~N}_{3}\right)$ and $101.093 \mathrm{Da}\left(\mathrm{C}_{4} \mathrm{H}_{11} \mathrm{~N}_{3}\right)$ from the $[\mathrm{M}+2 \mathrm{H}]^{+\cdot}$ ion, and may be attributed to losses from the Arg side-chain (see Scheme 2). With the exception of the

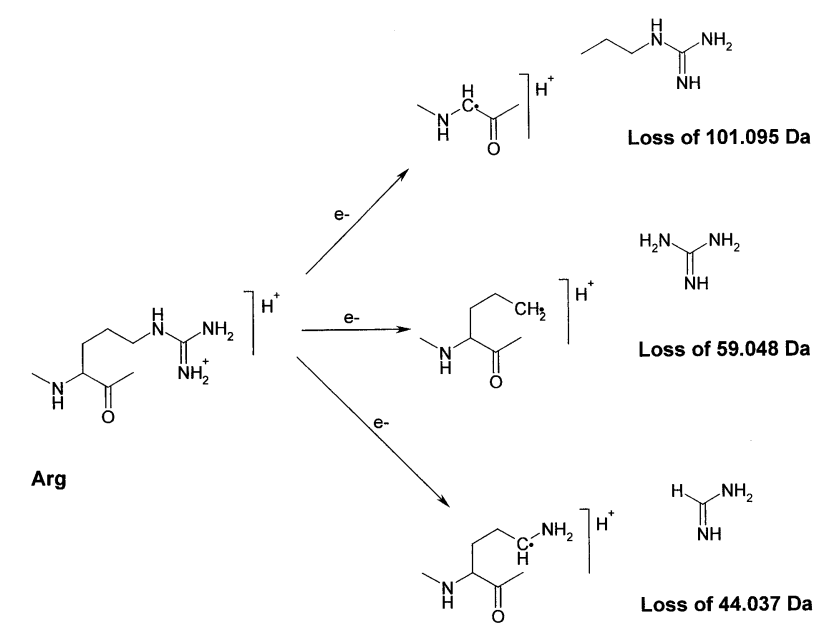

Scheme 2 


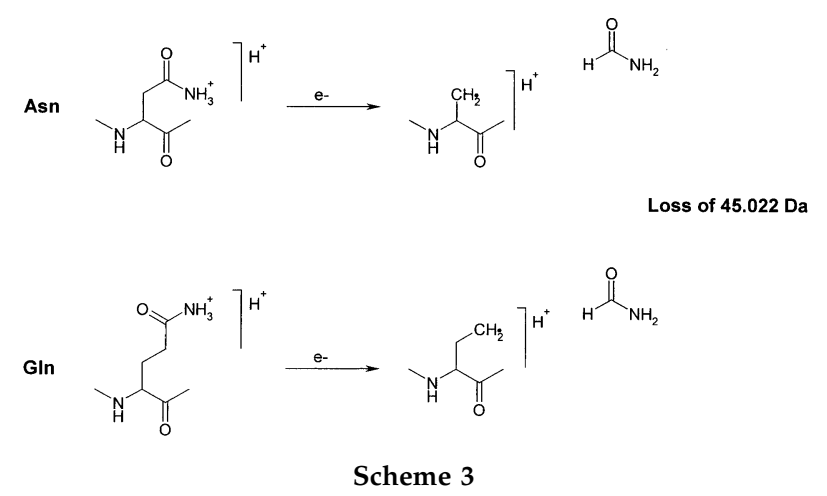

disulfide-linked dimer of AcCAAAAAK, all of the peptides contain Arg and show some combination of these losses. A peak at 101.095 Da less than the mass of the $[\mathrm{M}+2 \mathrm{H}]^{+\cdot}$ ion was observed in the ECD spectrum of doubly-protonated RPPGFSPFROCH$H_{3}$. All of the peptides containing Arg showed peaks corresponding to losses of $59.05 \mathrm{Da}$ from the $[\mathrm{M}+2 \mathrm{H}]^{+\cdot}$ ion. RSHRGHR was the only peptide to show a loss of $34.048 \mathrm{Da}\left(\mathrm{N}_{2} \mathrm{H}_{6}\right.$, two ammonia molecules, $34.053 \mathrm{Da}$, from the Arg side chain) from $[\mathrm{M}+2 \mathrm{H}]^{+\cdot}$ in its $\mathrm{ECD}$ spectrum. The ECD spectra of dynorphin A fragment 1-13, RSHGHR, and RPPGFSPFROCH ${ }_{3}$ showed peaks corresponding to losses of $44.034,44.037$, and $44.033 \mathrm{Da}$ from the $[\mathrm{M}+2 \mathrm{H}]^{+\cdot}$ ion respectively. These losses correspond to the elemental composition, $\mathrm{CH}_{4} \mathrm{~N}_{2}$ (44.037 Da) (see Scheme 2). For LHRH, a loss of 43.027 Da was observed and attributed to the loss of the neutral radical, $\mathrm{CH}_{3} \mathrm{~N}_{2} \cdot(43.029 \mathrm{Da})$ from the $[\mathrm{M}+2 \mathrm{H}]^{+\cdot}$ ion.

A peak corresponding to a loss of $\sim 45 \mathrm{Da}$ from the $[\mathrm{M}+2 \mathrm{H}]^{+\cdot}$ ion was observed in the ECD spectra of neurotensin (45.021 Da), bombesin (45.023 Da), ALANGMARSHALL (45.024 Da), ALANGFARSHALL (45.021 Da), and ALANGPARSHALF (45.022 Da). This loss corresponds to the elemental composition, $\mathrm{CH}_{3} \mathrm{NO}$ (45.022 Da), and is attributed to fragmentation within an Asn or Gln (bombesin only) side chain (see Scheme 3). It is unlikely that this product results from an amidated C-terminus because both bombesin and LHRH are amidated but only bombesin showed this product ion.

Neurotensin and bombesin were unusual in that their ECD spectra showed losses of 27.999 and 27.992 Da respectively from the $[\mathrm{M}+2 \mathrm{H}]^{+\cdot}$ ion. These losses correspond to CO $(27.995 \mathrm{Da})$, which is difficult to justify mechanistically. Bombesin also showed a loss of 74.021 Da from the $[\mathrm{M}+2 \mathrm{H}]^{+\cdot}$ ion, attributed to the elemental composition, $\mathrm{C}_{3} \mathrm{H}_{6} \mathrm{~S}(74.019 \mathrm{Da})$, i.e., a side chain loss from Met (see Scheme 4). This loss was not observed for the other Met-containing peptide (ALANGMARSHALL) and may be due to the proximity of Met to the C-terminus. (A $73 \mathrm{Da}$ loss was observed for the peptide, ALANGMARSHALL, corresponding to a y ion-not to be confused possibly with a Met-side chain

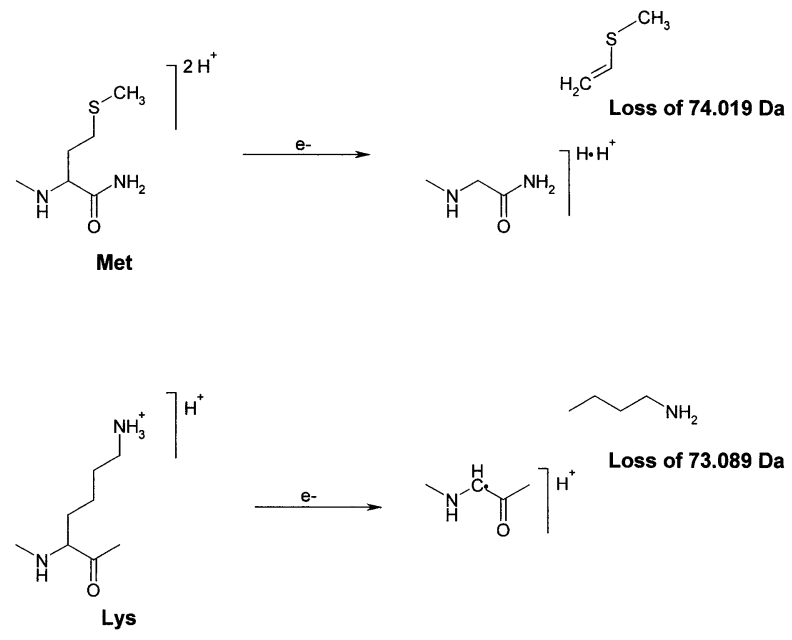

Scheme 4

loss. That ion was also observed in the ECD spectra of ALANGFARSHALL and ALANGPARSHALF).

The ECD spectra of most of the peptides showed peaks corresponding to the loss of ammonia from the $[\mathrm{M}+2 \mathrm{H}]^{+\cdot}$ ion. In the original ECD paper [1], such a loss was attributed to fragmentation of the Lys side chain. However, the monomer (results not shown) and dimer of AcCAAAAAK (Figure 10) show no ammonia loss. The only potential site of ammonia loss in these peptides is Lys, and they were the only peptides for which ammonia loss was not observed. Thus, either ammonia loss from lysine does not occur or its mechanism requires the presence of another amino acid. The ammonia loss observed in the remaining peptides could result from the Arg (all), Asn (neurotensin, bombesin, ALANGMARSHALL suite) or Gln (bombesin) side chains, or from the C-terminus of LHRH or bombesin.

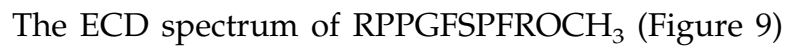
contains several interesting peaks. In addition to the side-chain losses described above, losses of 18.010, $32.020,35.042,36.017,86.070$, and $99.078 \mathrm{Da}$ from the $[\mathrm{M}+2 \mathrm{H}]^{+\cdot}$ ion were observed. A loss of $32.020 \mathrm{Da}$ corresponds to a methanol molecule $(32.026 \mathrm{Da})$ from the C-terminus. Losses of 18.010 and $36.017 \mathrm{Da}$ correspond to losses of one and two water molecules (18.0106 Da each). The remaining losses correspond to elemental compositions $\mathrm{H}_{4} \mathrm{NO}(35.037 \mathrm{Da}), \mathrm{C}_{3} \mathrm{H}_{8} \mathrm{~N}_{3}$ (86.072 Da), and $\mathrm{C}_{4} \mathrm{H}_{9} \mathrm{~N}_{3}(99.068 \mathrm{Da})$. None of these losses is typical. In this peptide, one of the charged Arg residues adjoins a non-standard C-terminus. These losses likely result from the interaction of the Arg side chain with the methoxy C-terminus.

Table 1 summarizes the observed losses, according to particular amino acids in each peptide. It is interesting to note that side-chain losses are observed only for basic residues, i.e., those likely to carry the charge and capture the electron. 
Table 1. Side chain losses from amino acid residues following ECD of doubly-protonated peptides

\begin{tabular}{|c|c|c|c|c|c|c|c|c|c|c|c|}
\hline & Arg losses & & & & & His losses & & Asn/Gln losses & & Met losses & \\
\hline Peptide & Present? & 34 & 44 & 59 & 101 & Present? & 82 & Present? & 45 & Present? & 74 \\
\hline LHRH $p E H W S Y G L R P G N H_{2}$ & $\sqrt{ }$ & $\mathrm{N}$ & $Y^{*}$ & $\mathrm{Y}$ & $\mathrm{Y}$ & $\sqrt{ }$ & $\mathrm{Y}$ & $\mathrm{X}$ & $\mathrm{N}$ & $\mathrm{X}$ & $\mathrm{N}$ \\
\hline $\begin{array}{l}\text { Neurotensin } \\
\text { pELYENKPRRPYIL }\end{array}$ & $\checkmark$ & $\mathrm{N}$ & $\mathrm{N}$ & $\mathrm{Y}$ & $\mathrm{N}$ & $\mathrm{X}$ & $\mathrm{N}$ & $\sqrt{ }$ & $\mathrm{Y}$ & $\mathrm{X}$ & $\mathrm{N}$ \\
\hline $\begin{array}{l}\text { Bombesin } \\
\text { pEQRLGNOWAVGHLMNH }{ }_{2}\end{array}$ & $\checkmark$ & $\mathrm{N}$ & $\mathrm{N}$ & $\mathrm{Y}$ & $\mathrm{N}$ & $\checkmark$ & $\mathrm{Y}$ & $\sqrt{ }$ & $\mathrm{Y}$ & $\checkmark$ & Y \\
\hline $\begin{array}{l}\text { Dynorphin A Fragment 1- } \\
13 \text { YGGFLRRIRPKLK }\end{array}$ & $\sqrt{ }$ & $\mathrm{N}$ & $\mathrm{Y}$ & $\mathrm{Y}$ & $\mathrm{N}$ & $X$ & $\mathrm{~N}$ & $X$ & $\mathrm{~N}$ & $X$ & $\mathrm{~N}$ \\
\hline ALANGMARSHALL & $\checkmark$ & $\mathrm{N}$ & $\mathrm{N}$ & $\mathrm{Y}$ & $\mathrm{N}$ & $\checkmark$ & $\mathrm{Y}$ & $\sqrt{ }$ & $\mathrm{Y}$ & $\sqrt{ }$ & $\mathrm{N}$ \\
\hline ALANGFARSHALL & $\sqrt{ }$ & $\mathrm{N}$ & $\mathrm{N}$ & $\mathrm{Y}$ & $\mathrm{N}$ & $\sqrt{ }$ & $\mathrm{Y}$ & $\sqrt{ }$ & $\mathrm{Y}$ & $x$ & $\mathrm{~N}$ \\
\hline ALANGPARSHALF & $\sqrt{ }$ & $\mathrm{N}$ & $\mathrm{N}$ & $\mathrm{Y}$ & $\mathrm{N}$ & $\checkmark$ & $\mathrm{Y}$ & $\sqrt{ }$ & $\mathrm{Y}$ & $x$ & $\mathrm{~N}$ \\
\hline RSHRGHR & $\sqrt{ }$ & $\mathrm{Y}$ & $\mathrm{Y}$ & $\mathrm{Y}$ & $\mathrm{N}$ & $\checkmark$ & $\mathrm{Y}$ & $x$ & $\mathrm{~N}$ & $x$ & $\mathrm{~N}$ \\
\hline $\mathrm{RPPGFSPFROCH}_{3}$ & $\checkmark$ & $\mathrm{N}$ & $\mathrm{Y}$ & $\mathrm{Y}$ & $\mathrm{Y}$ & $\mathrm{X}$ & $\mathrm{N}$ & $x$ & $\mathrm{~N}$ & $\mathrm{X}$ & $\mathrm{N}$ \\
\hline$(\text { AccCAAAAAK })_{2}$ & $x^{a}$ & $\mathrm{~N}$ & $\mathrm{~N}$ & $\mathrm{~N}$ & $\mathrm{~N}$ & $x$ & $\mathrm{~N}$ & $x$ & $\mathrm{~N}$ & $x$ & $\mathrm{~N}$ \\
\hline
\end{tabular}

* Loss of 43 observed-see text.

${ }^{\mathrm{a}} \mathrm{X}=$ Not present.

\section{Relative Abundances of Ions Resulting from Side- Chain Cleavages}

In some cases, ions due to side-chain cleavages constitute major components of the ECD spectrum. The best example is the ECD spectrum of RSHRGHR (Figure 8). Generally, the most abundant product of electron capture is the $[\mathrm{M}+\mathrm{nH}]^{(\mathrm{n}-1)+\cdot}$ ion (for which $[\mathrm{M}+\mathrm{nH}]^{\mathrm{n}+}$ is the precursor ion). However, in this spectrum the Arg side-chain loss (-59 Da) was the most abundant product, presumably due to the high percentage of this amino acid in the peptide. For dynorphin A fragment 1-13 and RPPGFSPFROCH${ }_{3}$, the corresponding product ion magnitude was greater than $50 \%$ that of the $[\mathrm{M}+2 \mathrm{H}]^{+\cdot}$ ion and comparable to the backbone fragments. In the neurotensin ECD spectrum, the corresponding product ion magnitude was $15 \%$ that of the $[\mathrm{M}+2 \mathrm{H}]^{+}$ion, $34 \%$ of the $\mathrm{z}_{12} \cdot$ ion, $83 \%$ of the $\mathrm{c}_{13}$ ion, and greater than any of the remaining product ions.

In the LHRH ECD spectrum, the abundance of the ion resulting from His side-chain loss was $43 \%$ that of the $[\mathrm{M}+2 \mathrm{H}]^{+}$ion, $59 \%$ of the most abundant backbone ion $\left(\mathrm{z}_{6} \cdot\right)$ and greater than any of the remaining ions. The abundance of the product ion resulting from Met sidechain loss in ECD of bombesin was $21 \%$ that of the major backbone fragment $\left(c_{8}\right)$ and comparable to the other observed backbone fragments.

\section{Triply-Protonated Peptide Ions}

The ECD FT-ICR mass spectra of the triply-protonated peptides, neurotensin and dynorphin A fragment 1-13, are shown in Figures 11 and 12. The results are summarized in Table 2. Side-chain cleavages are even more extensive for the triply-protonated peptides. ECD of doubly-protonated neurotensin resulted in the loss of ammonia (from Arg or Asn), loss of $\mathrm{CH}_{3} \mathrm{NO}$ (from Asn), and $\mathrm{CH}_{5} \mathrm{~N}_{3}$ (from Arg). In the ECD of triply-protonated neurotensin, however, singly charged ions resulting from these losses were observed in addition to losses of
$\mathrm{N}_{2} \mathrm{H}_{6}$ (i.e., two molecules of ammonia) and $\mathrm{C}_{4} \mathrm{H}_{11} \mathrm{~N}_{3}$ from the Arg side-chain. Losses of ammonia, $\mathrm{CH}_{3} \mathrm{NO}$, and $\mathrm{CH}_{5} \mathrm{~N}_{3}$ from the $[\mathrm{M}+3 \mathrm{H}]^{2+\cdot}$ ion were also seen as doubly charged ions. The loss of $27.993 \mathrm{Da}$ from [M + $3 \mathrm{H}]^{2+}$. was seen as a doubly-protonated ion. That product was observed in the ECD of [neurotensin] $]^{2+}$ and is attributed to the loss of CO (27.995 Da). The peaks corresponding to side-chain losses in the ECD spectrum of [neurotensin] ${ }^{3+}$ are all of comparable abundance to the backbone fragment ions.

The ECD spectrum of doubly-protonated dynorphin A fragment 1-13 showed peaks corresponding to the losses of ammonia, $\mathrm{CH}_{4} \mathrm{~N}_{2}$, and $\mathrm{CH}_{5} \mathrm{~N}_{3}$ from the Arg side chain. The ECD spectrum of the triply-protonated ion showed peaks corresponding to these losses from both the $[\mathrm{M}+3 \mathrm{H}]^{+}$and $[\mathrm{M}+3 \mathrm{H}]^{2+\cdot}$ ions, i.e., both singly and doubly charged. Additionally, Arg sidechain losses of $\mathrm{N}_{2} \mathrm{H}_{6}$ (i.e., two molecules of ammonia) from $[\mathrm{M}+3 \mathrm{H}]^{+}$and $[\mathrm{M}+3 \mathrm{H}]^{2+\cdot}$ ions and $\mathrm{C}_{4} \mathrm{H}_{11} \mathrm{~N}_{3}$ from $[\mathrm{M}+3 \mathrm{H}]^{+}$were observed. This spectrum showed

Neurotensin:

pGlu-Leu-Tyr-Glu-Asn-Lys-Pro-Arg-Arg-Pro-Tyr-Ile-Leu

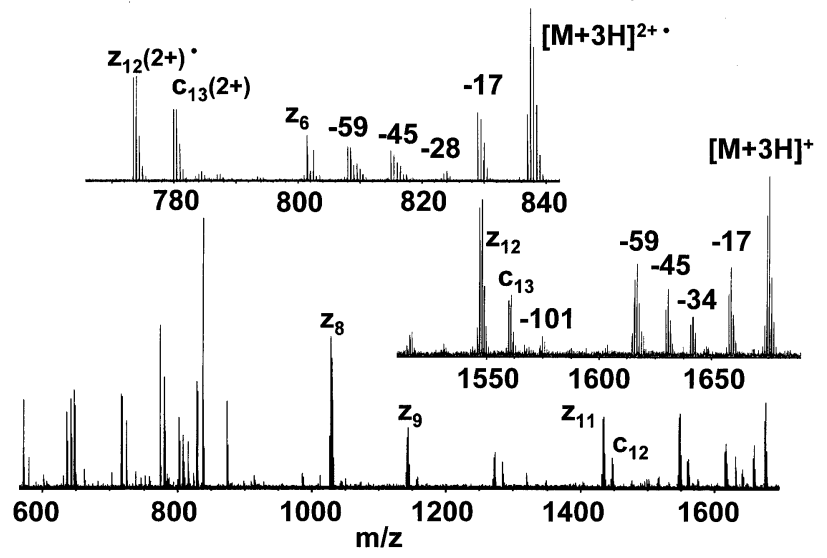

Figure 11. ESI ECD FT-ICR $m / z$ spectrum of neurotensin $[\mathrm{M}+$ $3 \mathrm{H}]^{3+}$. 
Dynorphin A Fragment 1-13:

Tyr-Gly-Gly-Phe-Leu-Arg-Arg-lle-Arg-Pro-Lys-Leu-Lys

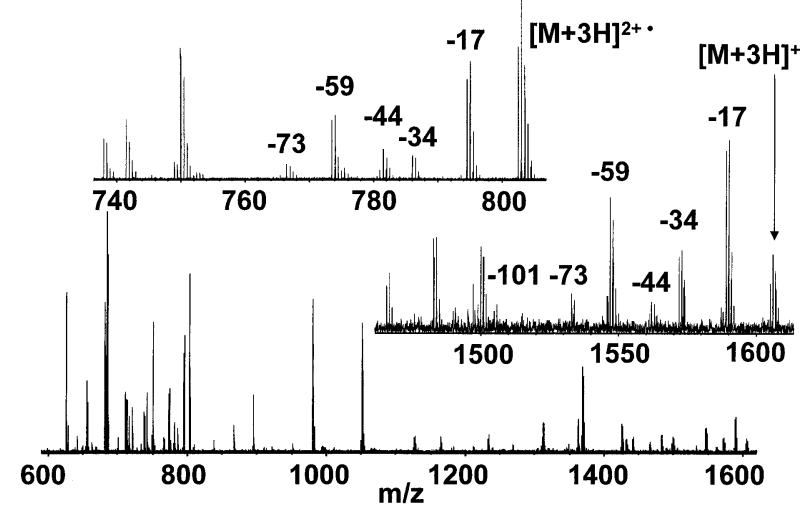

Figure 12. ESI ECD FT-ICR $\mathrm{m} / \mathrm{z}$ spectrum of dynorphin A fragment $1-13[\mathrm{M}+3 \mathrm{H}]^{3+}$.

a peak corresponding to a loss of $73.080 \mathrm{Da}$ from the [M $+3 \mathrm{H}]^{+}$ion and one corresponding to a loss of 73.089 Da from the $[\mathrm{M}+3 \mathrm{H}]^{2+}$ ion, namely, a loss of $\mathrm{C}_{4} \mathrm{H}_{11} \mathrm{~N}$ (73.089 Da), i.e., a lysine side chain (see Scheme 4). Such behavior was observed only for this peptide. Again, the magnitudes of the peaks corresponding to the products of side chain cleavage were comparable to those corresponding to the products of backbone cleavage. No peaks corresponding to the products of cleavages within two side chains were observed in either the [neurotensin] $^{3+}$ or the [dynorphin A fragment 1-13] ${ }^{3+}$ ECD spectrum.

\section{Conclusion}

The ECD ESI FT-ICR mass spectra of the peptides studied show a number of products resulting from side-chain cleavage. The magnitudes of the side-chain loss peaks were comparable to those relating to backbone cleavage for all ten of the peptides considered here. Side-chain fragmentation appears to occur exclusively in basic residues, i.e., those residues likely to carry the positive charge and capture the electron. All peptides containing arginine exhibited losses associated with the Arg side chain. The loss of $\mathrm{CH}_{5} \mathrm{~N}_{3}$ was particularly dominant and for the peptide RSHRGHR was the most abundant product of ECD. This result was unexpected because by far the most abundant ECD product is typically that in which an electron is cap- tured and no dissociation occurs. All peptides containing histidine showed cleavage of the side-chain, irrespective of its sequence position. We infer that His need not be in close proximity to the C-terminus for such loss to occur. Fragmentation within the asparagine or glutamine side chain resulting in the loss of $\mathrm{CH}_{3} \mathrm{NO}$ was observed for all peptides containing those residues. This loss had not been reported previously. Another previously unreported fragmentation within the methionine side chain was observed for bombesin, but was not observed for the other Met-containing peptide (ALANGMARSHALL).

With the exception of the disulfide-linked dimer of AcCAAAAAK, all ten peptides showed loss of ammonia. If ammonia loss were associated with the Lys side chain, it would be expected for this peptide as well. We therefore conclude either that ammonia is not lost from lysine or that ammonia loss from lysine involves another amino acid in the reaction. Ammonia loss could result from Arg cleavage (all ten peptides) or Asn/Gln or amidated C-termini cleavage for peptides containing these residues. The peptide, RPPGFSPFROCH $\mathrm{H}_{3}$, exhibited extensive fragmentation of the Arg side chain and loss of water. Such behavior is presumably due to the proximity of the Arg residue to the non-standard methoxy C-terminal group.

Increased charge on the peptides resulted in increased side-chain cleavage. For example, ECD of the doubly-protonated neurotensin ion resulted in the loss of ammonia (from Arg or Asn), a loss of $\mathrm{CH}_{3} \mathrm{NO}$ (from Asn), and $\mathrm{CH}_{5} \mathrm{~N}_{3}$ (from Arg), whereas ECD of the triply-protonated neurotensin ion resulted in these losses plus losses of $\mathrm{N}_{2} \mathrm{H}_{6}$ (i.e., two molecules of ammonia) and $\mathrm{C}_{4} \mathrm{H}_{11} \mathrm{~N}_{3}$ from the Arg side chain, and the loss of either $\mathrm{CO}$ or $\mathrm{N}_{2}$. The ECD spectrum of triply-protonated dynorphin A fragment 1-13 showed the loss of a lysine side chain, a result not found for any other lysine containing peptide nor in the ECD spectrum of doubly-protonated dynorphin A fragment 1-13.

In summary, side-chain cleavage appears to be a non-negligible pathway in peptide ion dissociation following electron capture. Fragmentations of this type should therefore be borne in mind in analysis of ECD data, and could be of added diagnostic value in identifying arginine, histidine, and asparigine/glutamine in unknown peptides.

Table 2. Side chain losses from amino acid residues following ECD of triply-charged peptides

\begin{tabular}{|c|c|c|c|c|c|c|c|c|c|c|c|}
\hline & Arg losses & & & & & His losses & & Asn/GIn losses & & Lys losses & \\
\hline Peptide & Present & 34 & 44 & 59 & 101 & Present? & 82 & Present? & 45 & Present? & 73 \\
\hline $\begin{array}{l}\text { Neurotensin } \\
\text { pELYENKPRRPYIL }\end{array}$ & $\checkmark$ & $\mathrm{Y}$ & $\mathrm{N}$ & $\mathrm{Y}$ & $\mathrm{Y}$ & $x^{a}$ & $\mathrm{~N}$ & $\checkmark$ & $\mathrm{Y}$ & $x$ & $\mathrm{~N}$ \\
\hline $\begin{array}{l}\text { Dynorphin A Fragment 1-13 } \\
\text { YGGFLRRIRPKLK }\end{array}$ & $\checkmark$ & $\mathrm{Y}$ & $\mathrm{Y}$ & $\mathrm{Y}$ & $\mathrm{Y}$ & $X$ & $\mathrm{~N}$ & $\mathrm{X}$ & $\mathrm{N}$ & $\checkmark$ & $Y$ \\
\hline
\end{tabular}

${ }^{\mathrm{a} X}=$ Not present. 


\section{Acknowledgments}

The authors thank Mark R. Emmett and Christopher L. Hendrickson for helpful discussions, Umesh Goli for synthesis of some of the peptides, and John P. Quinn for development of ECD on the 9.4T instrument. This work was supported by the NSF National High-Field FT-ICR Mass Spectrometry Facility (CHE 99-09502), Florida State University, and the National High Magnetic Field Laboratory at Tallahassee, Florida, and the Swedish Foundation for International Cooperation in Research and Higher Education (STINT).

\section{References}

1. Zubarev, R. A.; Kelleher, N. L.; McLafferty, F. W. Electron Capture Dissociation of Multiply Charged Proetin Cations. A Nonergodic Process. J. Am. Chem. Soc. 1998, 120, 3265-3266.

2. McLafferty, F. W.; Horn, D. M.; Breuker, K.; Ge, Y.; Lewis, M. A.; Cerda, B.; Zubarev, R. A.; Carpenter, B. K. Electron Captre Dissociation of Gaseous Multiply Charged Ions by Fourier Transform Ion Cyclotron Resonance. J. Am. Soc. Mass Spectrom. 2001, 12, 245-249.

3. Fenn, J. B.; Mann, M.; Meng, C. K.; Wong, S. F.; Whitehouse, C. M. Electrospray Ionization for Mass Spectrometry of Large Biomolecules. Science 1989, 246, 64-71.

4. Smith, R. D.; Loo, J. A. Ogorzalek; Loo, R. R.; Busman, M.; Udseth, H. R. Electrospray MS Review. Mass Spectrom. Rev. 1991, 10, 359-451.

5. Hendrickson, C. L.; Emmett, M. R. Electrospray Ionization Fourier Transform Ion Cyclotron Resonance Mass Spectrometry. Annu. Rev. Phys. Chem. 1999, 50, 517-536.

6. Lorenz, S. A.; Maziarz, E. P. I.; Wood, T. D. Electrospray Ionization Fourier Transform Mass Spectrometry of Macromolecules: The First Decade. Appl. Spectrosc. 1999, 53, 18A36A.

7. Comisarow, M. B.; Marshall, A. G. Fourier Transform Ion Cyclotron Resonance Spectroscopy. Chem. Phys. Lett. 1974, 25, 282-283.

8. Marshall, A. G.; Hendrickson, C. L.; Jackson, G. S. Fourier Transform Ion Cyclotron Resonance Mass Spectrometry: A Primer. Mass Spectrom. Rev. 1998, 17, 1-35.

9. McLafferty, F. W. High-Resolution Tandem FT Mass Spectrometry above $10 \mathrm{kDa}$. Acc. Chem. Res. 1994, 27, 379-386.

10. Gauthier, J. W.; Trautman, T. R.; Jacobson, D. B. Sustained Off-resonance Irradiation for CAD Involving FTMS. CAD Technique that Emulates Infrared Multiphoton Dissociation. Anal. Chim. Acta 1991, 246, 211-225.

11. Woodlin, R. L.; Bomse, D. S.; Beauchamp, J. L. Multiphoton Dissociation of Molecules with Low Power Continuous Wave Infrared Laser Radiation. J. Am. Chem. Soc. 1978, 100, 32483250.

12. Little, D. P.; Speir, J. P.; Senko, M. W.; O'Connor, P. B.; McLafferty, F. W. Infrared Multiphoton Dissociation of Large Multiply charged Ions for Biomolecule Sequencing. Anal. Chem. 1994, 66, 2809-2815.

13. Price, W. D.; Schnier, P. D.; Williams, E. R. Tandem Mass Spectrometry of Large Biomolecule Ions by Blackbody Infrared Radiative Dissociation. Anal. Chem. 1996, 68, 859-866.

14. Dunbar, R. C.; McMahon, T. B. Activation of Unimolecular Reactions by Ambient Blackbody Radiation. Science 1998, 279, 194-197.

15. Chorush, R. A.; Little, D. P.; Beu, S. C.; Wood, T. D.; McLafferty, F. W. Surface induced dissociation of multiply protonated proteins. Anal. Chem. 1995, 67, 1042-1046.

16. McCormack, A. L.; Jones, J. L.; Wysocki, V. H. Surface-Induced Dissociation of Multiply Protonated Peptides. J. Am. Soc. Mass Spectrom. 1992, 3, 859-862.
17. Håkansson, K.; Axelsson, J.; Palmblad, M.; Håkansson, P. Mechanistic Studies of Multipole Storage Assisted Dissociation. J. Am. Soc. Mass Spectrom. 2000, 11, 210-217.

18. Sannes-Lowery, K.; Griffey, R. H.; Kruppa, G. H.; Speir, J. P.; Hofstadler, S. A. Multipole Storage Assisted Dissociation, a Novel In-Source Dissociation Technique for Electrospray Ionization Generated Ions. Rapid Commun. Mass Spectrom. 1998, 12, 1957-1961.

19. Loo, J. A.; Edmonds, C. G.; Udseth, H. R.; Smith, R. D. Collisional Activation and Dissociation of Large Multiply Charged Proteins Produced by Electrospray Ionization. Anal. Chim. Acta 1990, 241, 167-173.

20. Roepstorff, P.; Fohlman, J. Proposal for Common Nomenclature for Sequence Ions in Mass Spectra of Peptides. Biomed. Mass Spectrom. 1984, 11, 601-601.

21. Zubarev, R. A.; Kruger, N. A.; Fridriksson, E. K.; Lewis, M. A.; Horn, D. M.; Carpenter, B. K.; McLafferty, F. W. Electron Capture Dissociation of Gaseous Multiply-Charged Proteins is Favoured at Disulphide Bonds and Other Sites of High Hydrogen Atom Affinity. J. Am. Chem. Soc. 1999, 121, 28572862.

22. Kruger, N. A.; Zubarev, R. A.; Carpenter, B. K.; Kelleher, N. L.; Horn, D. M.; McLafferty, F. W. Electron Capture versus Energetic Dissociation of Protein Ions. Int. J. Mass Spectrom. 1999, 182/183, 1-5.

23. Kruger, N. A.; Zubarev, R. A.; Horn, D. M.; McLafferty, F. W. Electron Capture Dissociation of Multiply Charged Peptide Cations. Int. J. Mass Spectrom. 1999, 185/186/187, 787-793.

24. Håkansson, K.; Emmett, M. R.; Hendrickson, C. L.; Marshall, A. G. High Sensitivity Electron Capture Tandem FT-ICR Mass Spectrometry of Microelectrosprayed Peptides. Anal. Chem. 2001, 73, 0000-0000.

25. Zubarev, R. A.; Horn, D. M.; Fridriksson, E. K.; Kelleher, N. L.; Kruger, N. A.; Lewis, M. A.; Carpenter, B. K.; McLafferty, F. W. Electron Capture Dissociation for Structural Characterization of Multiply Charged Protein Cations. Anal. Chem. 2000, 72, 563-573.

26. Horn, D. M.; Zubarev, R. A.; McLafferty, F. W. Automated de novo Sequencing of Proteins by tandem High-Resolution Mass Spectrometry. Proc. Nat. Acad. Sci. U.S.A. 2000, 97, 10313-10317.

27. Horn, D. M.; Ge, Y.; McLafferty, F. W. Activated Ion Electron Capture Dissociation for Mass Spectral Sequencing of Larger (42 kDa) Proteins. Anal. Chem. 2000, 72, 4778-4784.

28. Kelleher, N. L.; Zubarev, R. A.; Bush, K.; Furie, B.; Furie, B. C.; McLafferty, F. W.; Walsh, C. T. Localization of Labile Posttranslational Modifications by Electron Capture Dissociation: The Case of $\gamma$-Carboxyglutamic Acid. Anal. Chem. 1999, 71, $4250-4253$.

29. Mirgorodskaya, E.; Roepstorff, P.; Zubarev, R. A. Localization of O-Glycosylation Sites in Peptides by Electron Capture Dissociation in a Fourier Transform Mass Spectrometer. Anal. Chem. 1999, 71, 4431-4436.

30. Stensballe, A.; Jensen, O. N.; Olsen, J. V.; Haselmann, K. F.; Zubarev, R. A. Electron Capture Dissociation of Singly and Multiply Phosphorylated Peptides. Rapid Commun. Mass Spectrom. 2000, 14, 1793-1800.

31. Shi, S. D.-H.; Hemling, M. E.; Carr, S. A. Phosphopeptide/ Phosphoprotein Mapping by Electron Capture Dissociation Mass Spectrometry. Anal. Chem. 2001, 73, 19-22.

32. Håkansson, K.; Cooper, H. J.; Emmett, M. R.; Costello, C. E.; Marshall, A. G.; Nilsson, C. L. Electron Capture Dissociation and Infrared Multiphoton Dissociation MS/MS of an NGlycosylated Tryptic Peptide Yield Complementary Sequence Information. Anal. Chem. 2001, 73, 4530-4536.

33. Hudgins, R. R.; Håkansson, K.; Marshall, A. G. ECD on Disulfide Linked Helical Peptides. Measuring the Efficiency of 
ECd at Sites Remote from Electron Capture. Proceedings of the 49th ASMS Conference on Mass Spectrometry and Allied Topics; Chicago, IL, 2001; TPB 030.

34. Stephenson, J. L., Jr; Cargile, B. J.; McLuckey, S. A. Ion Trap Collisional Activation of Disulphide Linkage Intact and Reduced Multiply Protonated polypeptides. Rapid Commun. Mass Spectrom. 1999, 13, 2040-2048.

35. Hudgins, R. R.; Håkansson, K.; Marshall, A. G. In preparation 2001.

36. Haselmann, K. F.; Budnik, B. A.; Zubarev, R. A. Electron Capture Dissociation of b2+ Peptide Fragments Reveals the Presence of the Acylium Ion Structure. Rapid Commun. Mass Spectrom. 2000, 14, 2242-2246.

37. Senko, M. W.; Hendrickson, C. L.; Pasa-Tolic, L.; Marto, J. A.; White, F. M.; Guan, S.; Marshall, A. G. Electrospray Ionization FT-ICR Mass Spectrometry at 9.4 Tesla. Rapid Commun. Mass Spectrom. 1996, 10, 1824-1828.

38. Senko, M. W.; Hendrickson, C. L.; Emmett, M. R.; Shi, S. D.-H.; Marshall, A. G. External Accumulation of Ions for Enhanced Electrospray Ionization Fourier Transform Ion Cyclotron Resonance Mass Spectrometry. J. Am. Soc. Mass Spectrom. 1997, 8, 970-976.

39. Quinn, J. P.; Emmett, M. R.; Marshall, A. G. A Device for Fabrication of Emitters for Low-Flow Electrospray Ionization. Proceedings of the 46th ASMS Conference on Mass Spectrometry and Allied Topics; Orlando, FL, 1998; pp 1388-1388.

40. Chowdhury, S. K.; Katta, V.; Chait, B. T. An ElectrosprayIonization Mass Spectrometer With New Features. Rapid Commun. Mass Spectrom. 1990, 4, 81-87.

41. Beu, S. C.; Laude, D. A., Jr. Open Trapped Ion Cell Geometries for FT/ICR/MS. Int. J. Mass Spectrom. Ion Proc. 1992, 112, 215-230.

42. Malmberg, J. H.; O'Neil, T. M. Pure Electron Plasma, Liquid, and Crystal. Phys. Rev. Lett. 1977, 39, 1333-1336.

43. Marshall, A. G.; Wang, T.-C. L.; Ricca, T. L. Tailored Excitation for Fourier Transform Ion Cyclotron Resonance Mass Spectrometry. J. Am. Chem. Soc. 1985, 107, 7893-7897.
44. Wang, T.-C. L.; Ricca, T. L.; Marshall, A. G. Extension of Dynamic Range in Fourier Transform Ion Cyclotron Resonance Mass Spectrometry via Stored Waveform Inverse Fourier Transform Excitation. Anal. Chem. 1986, 58, 2935-2938.

45. Guan, S.; Marshall, A. G. Stored Waveform Inverse Fourier Transform (SWIFT) Ion Excitation in Trapped-Ion Mass Spectrometry: Theory and Applications. Int. J. Mass Spectrom. Ion Processes 1996, 157/158, 5-37.

46. Quinn, J. P.; Håkansson, K.; Hudgins, R. R.; Hendrickson, C. L.; Marshall, A. G. Novel Implementation of Electron Capture Dissociation for Fourier Transform Ion Cyclotron Resonance Mass Spectrometry. Proceedings of the 49th ASMS Conference on Mass Spectrometry and Allied Topics; Chicago, IL, 2001; WPM Z71.

47. Marshall, A. G.; Roe, D. C. Theory of Fourier Transform Ion Cyclotron Resonance Mass Spectroscopy: Response to Frequency-Sweep Excitation. J. Chem. Phys. 1980, 73, 1581-1590.

48. Marshall, A. G.; Verdun, F. R. Fourier Transforms in NMR, Optical, and Mass Spectrometry: A User's Handbook. Elsevier: Amsterdam, 1990 pp 47-51, 80-82.

49. Senko, M. W.; Canterbury, J. D.; Guan, S.; Marshall, A. G. A High-Performance Modular Data System for FT-ICR Mass Spectrometry. Rapid Commun. Mass Spectrom. 1996, 10, 18391844.

50. Ledford, E. B., Jr.; Rempel, D. L.; Gross, M. L. Space Charge Effects in Fourier Transform Mass Spectrometry. Mass Calibration. Anal. Chem. 1984, 56, 2744-2748.

51. Shi, S. D.-H.; Drader, J. J.; Freitas, M. A.; Hendrickson, C. L.; Marshall, A. G. Comparison and Interconversion of the Two Most Common Frequency-to-Mass Calibration Functions for Fourier Transform Ion Cyclotron Resonance Mass Spectrometry. Int. J. Mass Spectrom. 2000, 195/196, 591-598.

52. Blakney, G. T.; van der Rest, G.; Johnson, J. R.; Freitas, M. A.; Drader, J. J.; Shi, S. D.-H.; Hendrickson, C. L.; Kelleher, N. L.; Marshall, A. G. Further Improvements to the MIDAS Data Station for FT-ICR Mass Spectrometry. Proceedings of the 49th ASMS Conference on Mass Spectrometry and Allied Topics; Chicago, IL, 2001; WPM265. 